\title{
Etos Kerja Pendeta BNKP
}

\section{The Work Ethics of the Pastors in the Church of BNKP}

\section{Otoriteit Dachi \& Delipiter Lase}

\author{
STT Banua Niha Keriso Protestan Sundermann Nias \\ ritterdachi@sttsundermann.ac.id \\ piterlase@sttsundermann.ac.id
}

\section{ARTICLE INFO}

Submitted: Click or tap to enter a date

Review: Click or tap to enter a date

Accepted: Click or tap to enter a date

Published: Click or tap to enter a date

\section{KEYWORDS}

BNKP, work ethics, Nias, pastor

\section{CORESPONDENCE}

Phone:

E-mail: ritterdachi@sttsundermann.ac.id

\begin{abstract}
A B S T R ACT
This article is a research article on the work ethic of the Pastor at the Banua Niha Keriso Protestant (BNKP) church. This topic is essential to study considering BNKP as a church organization has a general program of BNKP services whose implementation is elaborated through service at the synodal level, resorts, and congregations. The successful implementation of the program is highly dependent on the quality of the work ethic of the servants (pastors) at each level. With a qualitative-descriptive research approach, it was found that out of 60 BNKP Priests as participants, and they had different work ethic qualities. As many as $39.26 \%$ had a high work ethic, $33.33 \%$ moderate category, and $27.41 \%$ low category; equivalent to every ten pastors, four pastors have a high work ethic, three are medium, and three are flat. This research also succeeded in formulating the factors that influence the work ethic in the context of BNKP services, including the crisis of vocation and vagueness of responsibility, the spirituality, and integrity, leadership, and differences in theological education background.
\end{abstract}

\begin{abstract}
A B S TRAK
Artikel ini merupakan artikel hasil penelitian tentang etos kerja Pendeta di gereja Banua Niha Keriso Protestan (BNKP). Topik ini penting untuk diteliti, mengingat BNKP sebagai organisasi gereja memiliki program umum pelayanan BNKP yang pelaksanaannya dijabarkan melalui pelayanan di aras sinodal, resort dan jemaat. Berhasilnya pelaksanaan program pelayanan umum dimaksud, sangat tergantung pada kualitas etos kerja para pelayan (Pendeta) di setiap aras. Dengan pendekatan penelitian kualitatifdesktiptif, ditemukan bahwa dari 60 orang Pendeta BNKP sebagai partisipan, memiliki kualitas etos kerja yang berbeda-beda. Sebanyak 39,26\% memiliki etos kerja dengan kategori tinggi, 33,33\% kategori sedang serta $27,41 \%$ kategori rendah. Data ini juga ekuivalen dengan setiap 10 (sepuluh) orang pendeta, terdapat 4 (empat) orang memiliki etos kerja dengan kategori tinggi, 3 (tiga) orang sedang dan 3 (tiga) orang rendah. Penelitian ini juga berhasil merumuskan faktor-faktor yang memengaruhi etos kerja dalam konteks pelayanan BNKP, di antaranya adalah adanya krisis panggilan dan kekaburan tanggung jawab, masakah spiritualitas dan integritas pendeta, kepemimpinan serta perbedaan latar belakang pendidikan teologi.
\end{abstract}

Kata kunci: BNKP. etos kerja, Nias, pendeta

\section{PENDAHULUAN}

$\mathbf{S}$ uksesnya pencapaian tujuan organisasi baik organisasi sekular maupun organisasi gereja, ditentukan oleh kinerja para pekerjanya serta model kepemimpinan yang baik yang diterapkan dalam organisasi. Dalam rangka 
mewujudkan visinya Banua Niha Keriso Kristen Protestan (BNKP) sebagai organisasi gereja memiliki rencana strategis lima tahunan atau dikenal dengan Program Umum Pelayanan BNKP (PUPB) yang pelaksanaannya dijabarkan melalui pelayanan di aras sinodal, resort dan jemaat. Berhasilnya pelaksanaan PUPB dimaksud, tentu sangat tergantung pada etos kerja para pelayan di masing-masing aras.

Dalam peraturan BNKP dijelaskan bahwa penanggungjawab program pelayanan baik di jemaat maupun di resort adalah pendeta jemaat atau pendeta resort. ${ }^{1}$ Artinya bahwa seorang pendeta harus memiliki keahlian dalam memimpin (leadership skills) dan juga kemampuan untuk mengelola (ability to manage) semua aset yang dimiliki organisasi baik sumber daya manusia maupun harta benda yang dimiliki. Hal itu dimaksudkan agar tujuan gereja melayani anggota jemaat untuk mandiri dalam iman dan mampu menjadi saksi di tengah dunia dapat diwujudkan.

Program Pelayanan BNKP terbagi atas lima bidang program, yakni marturia, diakonia, koinonia, didaskalia dan penatalayanan. Hasil pengamatan awal terlihat bahwa terdapat beberapa pendeta BNKP yang tidak melakukan tugas ini dengan optimal di tempat pelayanan baik di resort-resort maupun jemaat-jemaat di BNKP. Seberapa banyak para pendeta yang tidak mengoptimalkan pelaksanaan bidang program dan apa saja jenis program pelayanan yang kurang dioptimalkan serta bagaimana dampak terhadap perkembangan jemaat yang dilayani, menjadi substansi kajian dalam penelitian ini.

Walaupun pertumbuhan BNKP terkesan lamban (berjalan selangkah demi selangkah), namun BNKP terus berupaya menunaikan tugas panggilan melalui penataan program pelayanan secara sistematis dan berkesinambungan, dengan menyusun PUPB setiap lima tahun. Sejak tahun 1980, BNKP secara berturut-turut penyusunan program pelayanan yang digumuli dan disahkan melalui Persidangan Majelis Sinode BNKP. Dalam penelitian ini, dokumen PUPB 2012-2017, menjadi salah satu unit analisis.

1 BPMS-BNKP, "Peraturan Banua Niha Keriso Protestan Nomor 04/BPMS-BNKP/2008 Tentang Jemaat Di BNKP" (Gunungsitoli: LPLG-BNKP, 2008).
Bila mengevaluasi PUPB 2012-2017, maka secara menyeluruh dapat dikatakan bahwa pelaksanaannya belum optimal, sehingga target capai atau tujuan yang direncanakan masih jauh dari yang diharapkan. Hal tersebut terjadi karena beberapa faktor antara lain (1) sumber daya manusia yang masih terbatas, baik pelayan (pendeta) maupun warga jemaat; (2) keterbatasan dana dalam melaksanakan program yang telah direncanakan; (3) kelemahan manajerial, mulai dari aras sinodal hingga aras jemaat, dan (4) ketidakseragaman kemampuan dalam perencanaan, pelaksanaan dan pengawasan program di setiap aras pelayanan. ${ }^{2}$

Gereja BNKP memiliki 59 wilayah Resort 1090 jemaat, dengan jumlah warga mencapai 429.000 jiwa yang dilayani oleh 538 pendeta, (Laporan BPHMS tahun 2015). Pelayanan BNKP tersebar di seluruh wilayah Indonesia, dan berpusat di Gunungsitoli. Pelayanan gereja BNKP $80 \%$ berada di wilayah pedesaan, dan $20 \%$ berada di daerah kota. Sejarah pelayanan BNKP, memberi gambaran bahwa BNKP tidak saja terpanggil untuk melaksanakan pelayanan di bidang rohani tetapi juga memberi perhatian pada segala aspek kehidupan umat. Itulah yang menjadi visi dan misi BNKP dalam pelayanan.

Namun pada kenyataannya ditemui beberapa kelemahan dalam pelaksanaan di antaranya (a) Penghayatan dan pengamalan iman yang statis cenderung sekedar rutinitas seremonial semata, (b) Para pelayan yang masih belum menghayati tugas panggilannya, (c) Adanya sebagian para pelayan sibuk karena tugas rangkap (d) Sumber daya manusia yang belum merata di setiap jemaat, (e) Belum meratanya pelaksanakan peraturan-peraturan yang telah ditetapkan di BNKP, (f) Kurangnya motivasi pengembangan diri para pelayan untuk mengembangkan pola pelayanan, (g) Kurangnya sarana yang dibutuhkan untuk mengembangkan diri dalam pelayanan, (h) Etos kerja para pelayan yang belum maksimal, (j) Masih adanya warga jemaat yang labil terhadap pengaruh luar, $(j)$ Tingkat loyalitas sebagian para pelayan masih rendah, dan (k) sebagian besar masyarakat masih hidup di bawah garis kemiskinan. ${ }^{3}$

2 Otoriteit Dachi et al., Pergumulan Di Sekitar Gereja Dan Pendidikan, ed. Delipiter Lase and Fotani Ziliwu (Yogyakarta: Andi Offset, 2019). 3 Ibid. 
Fokus masalah yang akan dikaji dalam penelitian ini adalah etos kerja pendeta di BNKP, dengan tujuan untuj pertama, memperoleh gambaran tentang etos kerja para pendeta BNKP dalam melaksanakan tugas pelayanan baik di resort maupun jemaat. Kedua, mengidentifikasi dan menganalisis hal-hal yang mempengaruhi tingkat etos kerja pendeta dalam pelayanan di jemaat dan resort. Yang menjadi dasar penilaian etos kerja didasarkan pada fungsi dan tugas pokok seorang pendeta yang melajani di BNKP. Hal ini telah diatur dalam Peraturan BNKP No. 07/BPMS-BNKP/2008. Etos kerja seorang pendeta merupakan faktor utama memberhasilkan pelaksanaan PUPB yang disusun setiap 5 (lima) tahun dan dijabarkan dalam program tahunan pelayanan BNKP.

\section{Kerangka Konseptual Etos Kerja}

Secara etimologis istilah etos berasal dari bahasa Yunani yang berarti 'tempat hidup'. Mula-mula tempat hidup dimaknai sebagai adat istiadat atau kebiasaan. Sejalan dengan waktu, kata etos berkembang dan berubah makna menjadi semakin kompleks. Dari kata yang sama muncul pula istilah Ethikos yang berarti 'teori kehidupan', yang kemudian menjadi 'etika'. Aristoteles menggambarkan etos sebagai salah satu dari tiga mode persuasi selain logos dan pathos dan mengartikannya sebagai 'kompetensi moral'. Tetapi Aristoteles berusaha memperluas makna istilah ini hingga 'keahlian' dan 'pengetahuan' tercakup di dalamnya. Ia menyatakan bahwa etos hanya dapat dicapai dengan apa yang dikatakan seorang pembicara, tidak dengan apa yang dipikirkan orang tentang sifatnya sebelum ia mulai berbicara.

Hornby \& Cowie mendefinisikan etos sebagai "the characteristic spirit, moral values, ideas or beliefs of a group, community or culture."4 Etos juga dapat dimaknai sebagai (1) The disposition, character, or attitude peculiar to a specific people, culture or a group that distinguishes it from other

${ }^{4}$ A.S. Hornby and A.P. Cowie, Oxford Advanced Learner's Dictionary of Current English, 5th ed. (Oxford University Press, 1995).

5 American Heritage Dictionary of the English Language, 5th ed. (Houghton Mifflin Harcourt, 2018).

${ }^{6}$ Pamdji Anoraga, Psikologi Kerja (Jakarta: Rineka Cipta, 2001).

${ }^{7}$ Ibid. peoples or group; fundamental values or spirit; mores. (2) The governing or central principles in a movement, work of art, mode of expression, or the like. ${ }^{5}$

Menurut Anoraga, etos kerja (work ethics) merupakan suatu pandangan dan sikap suatu bangsa atau umat terhadap kerja. ${ }^{6}$ Lebih lanjut dikatakan bahwa, bila individu-individu dalam komunitas memandang kerja sebagai suatu hal yang luhur bagi eksistensi manusia, maka etos kerjanya akan cenderung tinggi. Sebaliknya sikap dan pandangan terhadap kerja sebagai sesuatu yang bernilai rendah bagi kehidupan, maka etos kerja dengan sendirinya akan rendah. ${ }^{7}$ Earnestness or fervour in working, morale with regard to the tasks at hand (kesungguhan atau semangat dalam bekerja, suatu pandangan moral pada pekerjaan yang dilakoni). ${ }^{8}$

Sementara itu, Sinamo menjelaskan bahwa etos kerja adalah seperangkat perilaku positif yang berakar pada keyakinan fundamental yang disertai komitmen total pada paradigma kerja yang integral. 9 Ia memandang bahwa etos kerja merupakan fondasi dari sukses yang sejati dan otentik. Menurutnya, jika seseorang, suatu organisasi, atau suatu komunitas menganut paradigma kerja, mempercayai, dan berkomitmen pada paradigma kerja tersebut, semua itu akan melahirkan sikap dan perilaku kerja mereka yang khas. Itulah yang akan menjadi etos kerja dan budaya. Meskipun sebagian orang menyebut perilaku kerja ini sebagai motivasi, kebiasaan (habit) dan budaya kerja. Sinamo, lebih memilih menggunakan istilah etos karena menurutnya kata etos tidak saja menyangkut perilaku khas dari sebuah organisasi atau komunitas tetapi juga mencakup motivasi yang menggerakkan mereka, karakteristik utama, spirit dasar, pikiran dasar, kode etik, kode moral, kode perilaku, sikapsikap, aspirasi-aspirasi, keyakinan-keyakinan, prinsip-prinsip, dan standar-standar. ${ }^{10}$

Dari beberapa pendapat ahli di atas, baik secara etimologis maupun praktis, etos kerja

8 Merriam-Webster Incorporated, "MerriamWebster Dictionary," Merriam-Webster (Encyclopædia Britannica, Inc., 2018), last modified 2018, https://www.merriam-webster.com/.

9 Jansen Sinamo, Delapan Etos Kerja Profesional: Navigator Anda Menuju Sukses (Bogor: Grafika Mardi Yuana, 2005), 5.

10 Sinamo, Delapan Etos Kerja Profesional: Navigator Anda Menuju Sukses. 
dalam konteks penelitian ini didefinisikan sebagai seperangkat sikap atau pandangan mendasar yang dipegang sekelompok manusia untuk menilai bekerja sebagai suatu hal yang positif bagi peningkatan kualitas kehidupan sehingga mempengaruhi perilaku kerjanya.

Etos kerja memiliki empat pilar utama yang dikenal dengan sebutan Catur Dharma Mahardika ${ }^{11}$ (Empat Darma Keberhasilan Utama) yakni (a) Mencetak prestasi dengan motivasi superior, (b) Membangun masa depan dengan kepemimpinan visioner, (c) Menciptakan nilai baru dengan inovasi kreatif, dan (d) Meningkatkan mutu dengan keunggulan insani. Keempat darma kemudian dirumuskan ke dalam delapan aspek etos kerja, yakni kerja adalah (a) rahmat, (b) amanah, (c) panggilan, (d) aktualisasi, (f) seni, (g) kehormatan, dan (h) pelayanan.12 Beberapa sikap yang seharusnya mendasar bagi seseorang dalam memberi nilai pada kerja, yakni bekerja adalah hakikat kehidupan manusia; pekerjaan adalah suatu berkat Tuhan, sumber penghasilan yang halal dan tidak amoral, kesempatan untuk mengembangkan diri dan berbakti, serta sarana pelayanan dan perwujudan kasih. ${ }^{13}$

Suatu individu atau kelompok masyarakat dapat dikatakan memiliki Etos Kerja yang tinggi, apabila menunjukkan tanda-tanda seperti (a) mempunyai penilaian yang sangat positif terhadap hasil kerja manusia, (b) menempatkan pandangan tentang kerja, sebagai suatu hal yang amat luhur bagi eksistensi manusia, (c) kerja yang dirasakan sebagai aktivitas yang bermakna bagi kehidupan manusia, (d) kerja dihayati sebagai suatu proses yang membutuhkan ketekunan dan sekaligus sarana yang penting dalam mewujudkan cita-cita, dan (e) kerja dilakukan sebagai bentuk ibadah. ${ }^{14}$

\footnotetext{
11 Ibid.

12 Ibid.

${ }^{13}$ Anoraga, Psikologi Kerja.
}

14 Ahmad Kusnan, "Analisis Sikap Iklim Organisasi, Etos Kerja Dan Disiplin Kerja Dalam Menentukan Efektifitas Kinerja Organisasi Di Garnizun Tetap III Surabaya" (Universitas Airlangga, 2004), 27-28, http://repository.unair.ac. id/id/eprint/35933.

${ }^{15}$ Kusnan, "Analisis Sikap Iklim Organisasi, Etos Kerja Dan Disiplin Kerja Dalam Menentukan Efektifitas Kinerja Organisasi Di Garnizun Tetap III Surabaya."
Sebaliknya, individu atau kelompok masyarakat yang memiliki etos kerja yang rendah, ditunjukkan dengan ciri-ciri yaitu (a) kerja dirasakan sebagai suatu hal yang membebani diri, (b) kurang dan bahkan tidak menghargai hasil kerja manusia, (c) kerja dipandang sebagai suatu penghambat dalam memperoleh kesenangan, (d) kerja dilakukan sebagai bentuk keterpaksaan, dan (e) kerja dihayati hanya sebagai bentuk rutinitas hidup. ${ }^{15}$

Etos kerja individu atau masyarakat dipengaruhi oleh beberapa faktor, di antaranya adalah faktor agama. Weber memperlihatkan bahwa doktrin predestinasi dalam protestanisme mampu melahirkan etos berpikir rasional, berdisiplin tinggi, bekerja tekun sistematik, berorientasi sukses (material), tidak mengumbar kesenangan - namun hemat dan bersahaja (asketik), serta menabung dan berinvestasi, yang akhirnya menjadi titik tolak berkembangnya kapitalisme di dunia modern. ${ }^{1617}$ Berbagai studi tentang etos kerja berbasis agama sudah banyak dilakukan dengan hasil yang secara umum mengonfirmasi adanya korelasi positif antara sebuah sistem kepercayaan tertentu dan kemajuan ekonomi, kemakmuran, dan modernitas (Sinamo, 2005). ${ }^{18}$

Selain sistem kepercayaan (agama), kualitas etos kerja juga dapat ditentukan oleh sistem orientasi nilai budaya masyarakat yang bersangkutan. Masyarakat yang memiliki sistem nilai budaya maju akan memiliki etos kerja yang tinggi dan sebaliknya, masyarakat yang memiliki sistem nilai budaya yang konservatif akan memiliki etos kerja yang rendah, bahkan bisa sama sekali tidak memiliki etos kerja. ${ }^{19}$ Tinggi rendahnya etos kerja suatu masyarakat juga dipengaruhi oleh ada atau tidaknya struktur politik dan ekonomi yang mendorong masyarakat untuk bekerja keras dan dapat

${ }^{16}$ Max Weber, The Protestant Ethic and The Spirit of Capitalism (New York: Scribner, 1958).

${ }^{17}$ Max Weber, The Protestant Ethic and the Spirit of Capitalism, The Protestant Ethic and the Spirit of Capitalism (Routledge, 2005), https://www.taylorfrancis.com/books/9780203995808.

18 Sinamo, Delapan Etos Kerja Profesional: Navigator Anda Menuju Sukses.

19 Rosmiani, "Etos Kerja Nelayan Muslim Di Desa Paluh Sebaji Deli Serdang Sumatera Utara: Hubungan Antara Kualitas Keagamaan Dengan Etos Kerja" (Institut Agama Islam Negeri Jakarta, 1996). 
menikmati hasil kerja keras mereka dengan penuh. ${ }^{2021}$ Selain itu, etos kerja juga dapat muncul dikarenakan faktor kondisi geografis 22 Rahimah, dkk (1995) dalam Novliadi (2009), menjelaskan bahwa etos kerja tidak dapat dipisahkan dengan kualitas sumber daya manusia (pendidikan). Peningkatan sumber daya manusia akan membuat seseorang mempunyai etos kerja keras $^{23}$ serta oleh motivasi intrinsik individu itu sendiri. ${ }^{24}$

\section{METODE}

Penelitian ini menggunakan pendekatan kualitatif dengan metode deskriptif. Metode ini merupakan salah satu metode yang dipakai untuk menjawab pertanyaan penelitian tentang status terakhir dari subjek penelitian. ${ }^{2526}$ Sumber data terdiri dari para pendeta di BNKP yang melayani di aras jemaat dan resort. Penentuan sumber data dan informan menggunakan teknik purpose sampling, ${ }^{27}$ yakni didasarkan atas kompetensi dan bukan atas dasar keterwakilan (representativeness). ${ }^{28}$ Dalam konteks penelitin ini, sumber data (patisipan) berjumlah 60 orang pendeta di BNKP, yang ditetapkan dengan pertimbangan gender, tempat pelayanan (geografi) dan usia. Ke-60 sumber data tersebut berasal dari \pm 530 orang pendeta BNKP yang melayani di jemaat dan resort se-kepulauan Nias.

20 Soewarsono et al., Persepsi Tentang Etos Kerja Kaitannya Dengan Nilai Budaya Masyarakat (Jakarta: CV. Bupara Nugraha, 1995).

21 Salamun et al., Persepsi Tentang Etos Kerja: Kaitannya Dengan Nilai Budaya Masyarakat Daerah Istimewa Yogyakarta (CV.EKA PUTRA, 1995), http:/ / repositori.kemdikbud.go.id/12367/.

22 Liya Febriana Ayuningtyas, "Pengaruh Iklim Organisasi Terhadap Etos Kerja Karyawan..." (Universitas Muhammadiyah Purwokerto, 2011), 15.

23 Ferry Novliadi, "Hubungan Antara Organization-Based Self-Esteem Dengan Etos Kerja" (Universitas Sumatera Utara, 2009), 11, http://repository.usu.ac.id/bitstream/handle/12345 6789/3626/08E00921.pdf? sequence=1\&isAllowed=y.

${ }^{24}$ Anoraga, Psikologi Kerja.

25 Sonny Eli Zaluchu, "Strategi Penelitian Kualitatif Dan Kuantitatif Di Dalam Penelitian Agama," Evangelikal: Jurnal Teologi Injili dan Pembinaan Warga Jemaat 4, no. 1 (2020): 28-38.

26 W. L. Neuman, Metodologi Penelitian Sosial: Pendekatan Kualitatif Dan Kuantitatif, 7th ed. (Jakarta: PT. Index, 2016), 44.
Data dijaring dengan menggunakan metode gabungan observasi partisipan, ${ }^{29}$ wawancara mendalam dan focus group discussion (FGD). ${ }^{30}$ Siklus nalisa data meliputi pengumpulan dan reduksi data, penyajian dan penarikan kesimpulan. ${ }^{3132}$ Sedangkan pengujian keabsahan data ditunjukkan dalam bentuk teknik triangulasi yakni pengujian keabsahan data yang diperoleh dari berbagai sumber, metode, dan waktu. ${ }^{33}$

\section{HASIL DAN PEMBAHASAN}

Pada bagian pendahuluan telah dijelaskan bahwa tujuan penelitian ini adalah untuk memperoleh informasi tentang etos kerja pendeta di BNKP. Karena itu, fokus utama penelitian didasarkan pada fungsi, tugas dan tanggug jawab pendeta di BNKP yakni untuk melayani, memimpin dan mengelola kehidupan jemaat. Bila fungsi, tugas dan tanggung jawab ini dijabarkan lebih terperinci maka fungsi, tugas dan tanggungjawab tersebut akan tersermin pada aspek berikut ini. ${ }^{34}$

Pertama, pemberitaan firman Tuhan, baik dalam kebaktian Minggu maupun ibadah lainnya di jemaat. Kedua, pelaksanaan penggembalaan dan perkunjungan rumah tangga, termasuk pendampingan bagi anggota jemaat yang menghadapi masalah. Ketiga, kepemimpinan dalam Jemaat. Keempat,

${ }^{27}$ Earl R. Babbie, "The Practice of Social Research - Earl R. Babbie - Google Kitaplar," Cengage Learning.

$28 \mathrm{H}$ Russell Bernard, Reserach Methods in Anthropology - Qualitative and Quantitative Approaches, AltaMira Press, 2006.

${ }^{29}$ Lee H. Bowker, Robert Bogdan, and Steven J. Taylor, "Introduction to Qualitative Research Methods: A Phenomenological Approach to the Social Sciences," Teaching Sociology (1978): 41-76.

30 H. Russell Bernard, Research Methods in Anthropology: Qualitative and Quantitative Approaches (Walnut Creek: AltaMira Press, 1995).

31 M. Taylor, S. J., Bogdan, R., \& DeVault, Introduction to Qualitative Research Methods: A Guidebook and Resource (4th Edition), New York: John Wiley E Sons, 2015.

32 J Miles, M.B; Huberman, A.M; Sadana, "Chapter 4 Analyzing Qualitative Data," in Qualitative Data Analysis - A Methods Sourcebook, 2015.

33 Yvonna S Lincoln and Egon G Guba, Naturalist Inquiry, Beverly Hills, CA: Sage, 1985.

34 BPMS-BNKP, "Peraturan Banua Niha Keriso Protestan Nomor 04/BPMS-BNKP/2008 Tentang Jemaat Di BNKP." 
pengajaran di sekolah Sidi maupun Sekolah Minggu. Kelima, pelayan sakramen, serta pelaksanaan penggembalaan pra-Baptis dan praPerjamuan Kudus. Keenam, pelayanan diakonia gereja. Ketujuh, pembinaan persekutuan. Kedelapan, mengingat etos kerja sangat berkaitan erat dengan kedisiplinan dan pola hidup, maka dalam penelitian ini juga turut diteliti tentang kedisiplinan dalam melaksanakan tugas pelayanan dan terakhir, pola hidup yang dipraktekkan pendeta di tengah jemaat.

Tabel 1

Data Kulaitas Etos Kerja Pendeta BNKP tanggung jawab pelayanannya sebagaimana diatur peraturan BNKP No. 07/BPMS$\mathrm{BNKP} / 2008$, yakni pertama, tercapainya program pelayanan di jemaat yang sedang ia pimpin dan layani. Kedua, kemajuan jemaat baik dalam perkembangan iman, persekutuan maupun partisipasi dalam masyarakat. Ketiga, suksesnya pembenahan sarana dan prasarana dalam kegiatan pelayanan di jemaat. Keempat, suksesnya pengelolaan organisasi dan administrasi di Jemaat. Kelima, adanya berbagai terobosan baru atau inovasi yang dilakukan dalam pembinaan anggota jemaat, dan keenam, kemampuan pendeta membina hubungan dengan sesama pelayan dan anggota Jemaat.

\begin{tabular}{|c|c|c|c|c|c|c|c|c|c|c|c|}
\hline \multirow{2}{*}{$\begin{array}{c}\text { Level/ } \\
\text { Kategori }\end{array}$} & \multicolumn{9}{|c|}{ Aspek Penilaian } & \multirow{2}{*}{ Rerata } & \multirow{2}{*}{$\%$} \\
\hline & $1(1)$ & $1(2)$ & $1(3)$ & $1(4)$ & $1(5)$ & $1(6)$ & $1(7)$ & $1(8)$ & $1(9)$ & & \\
\hline Tinggi (70-100) & 20 & 13 & 26 & 20 & 28 & 32 & 11 & 28 & 34 & 23,56 & 39,26 \\
\hline Sedang (40-69) & 29 & 21 & 20 & 33 & 16 & 15 & 15 & 15 & 16 & 20,00 & 33,33 \\
\hline Rendah (0-39) & 11 & 26 & 14 & 7 & 16 & 13 & 34 & 17 & 10 & 16,44 & 27,41 \\
\hline Total & 60 & 60 & 60 & 60 & 60 & 60 & 60 & 60 & 60 & 60 & 100 \\
\hline
\end{tabular}

Untuk menilai dan menyimpulkan etos kerja pendeta di BNKP, peneliti menggunakan teknik Graphic Rating Scales, ${ }^{35}$ merupakan teknik penilaian kinerja yaitu evaluator menilai kinerja pegawai dengan menggunakan skala dalam mengukur faktor-faktor kinerja (performance factor). Metode ini merupakan metode umum yang paling banyak digunakan oleh organisasi. Namun untuk menyederhanakan penilaian etos kerja pendeta dalam penelitian ini hanya menggunakan tiga skala yakni 0-49 rendah, 50-69 sedang dan 70-100 tinggi.

Tabel 1 di atas menunjukkan bahwa kualitas etos kerja dari 60 partisipan (pendeta) yang melayani di aras jemaat dan resort di BNKP adalah sebanyak 24 orang $(39,26 \%)$ berada pada level/kategori tinggi, 20 orang (33,33\%) kategori sedang dan 16 orang $(27,43 \%)$ kategori rendah. Data ini dapat dimaknai bahwa setiap 10 orang pendeta, 4 orang di antaranya memiliki etos kerja yang tinggi, 3 orang beretos kerja sedang dan 3 orang berada pada level etos kerja rendah.

Kategori tinggi (70-100 \%) adalah penilaian bagi para pendeta yang memiliki etos kerja yang tinggi serta disiplin melaksanakan tugas dan

${ }^{35}$ R. Wayne Mondy, Robert M. Noe, and Shane R. Premeaux, Human Resource Management, 9th ed. (New Jersey: Prentice Hall, 2005), 402-414.
Kategori Sedang, adalah pelayanan para pendeta yang melayani secara rutin kebutuhan di jemaat namun belum terlihat ada inovasi dan peningkatan kualitas dalam pelayanan. Sedangkan pelayanan pendeta yang dengan kategori rendah adalah para pendeta yang tidak menyusun program pelayanan, kurang peduli pada kunjungan pastoral (pendampingan) serta pemberitaan firman Tuhan yang tidak membangun iman warga jemaat. Kurang bersinergitas dengan majelis dan badan pekerja majelis dalam kepemimpinan di jemaat. Keadaan pelayanan jemaat cenderung melemah, serta terdapat berbagai konflik dan permasalahan yang menuju pada perpecahan dan kemunduran iman Jemaat.

\section{Pemberitaan Firman Tuhan}

Dalam Pelayanan di BNKP, pemberitaan Firman Tuhan dilakukan melalui khotbah di mimbar gereja setiap hari Minggu dan hari-hari raya gerejani, pelaksanaan PA di lingkungan pelayanan, upacara-upacara seperti pemberkatan nikah, penguburan, pelaksanaan syukuran dan lain-lain. Kemampuan pendeta 
menerapkan berita firman Tuhan dalam berbagai peristiwa pelayanan ini serta pengetahuannya tentang kondisi pendengar khotbah sangat berperan penting untuk memberhasilkan suatu pemberitaan firman Tuhan yang bermuara pada pertumbuhan iman dan partisipasi anggota jemaat.

Pentingnya pemberitaan firman Tuhan yang baik kerena berhubungan erat dengan tugas memproklamirkan karya Yesus di tengahtengah dunia. Melalui pesan khotbah yang baik baik anggota jemaat merasakan damai sejahtera, pengampunan dosa, keselamatan, kedatangan kerajaan Allah. Melalui khotbah, berita keselamatan diterima oleh Jemaat, maka akan mendorong anggota jemaat menyatakannya dalam hidup dan sesamanya "Pergilah keseluruh dunia, beritakanlah Injil (keryxate to euangelion) kepada segala makhluk" (Mrk 16:15). ${ }^{36}$ Melalui khotbah, pendeta memberitahukan jemaatnya bahwa ia, maupun anggota jemaat, membutuhkan nasehat, teguran, atau dorongan. ${ }^{37}$

\section{Pendampingan dan Konseling Pastoral}

Pendampingan/perkunjungan atau konseling pastoral (pelayanan pribadi) sangat penting dalam mengoptimalkan pelayanan kepada anggota jemaat. Terlebih-lebih bagi mereka yang menghadapi sakit penyakit, masalah/konflik dan kehilangan. Data penelitian menunjukkan bahwa masih terdapat para pendeta yang belum memahami dengan sepenuhnya pentingnya pendampingan dan konseling bagi anggota jemaat. Pendeta hanya menunaikan tugasnya di atas mimbar (pendeta mimbar) tanpa melibatkan dirinya sendiri untuk mengenal dan memahami keadaan jemaat yang sesungguhnya. Pendeta mengabaikan hal ini karena menganggap tanggung jawab itu bisa dilaksanakan oleh para pelayan di bawahnya (Satua Niha Keriso) yang ada di jemaat.

Dalam tugas pelayanan ini, tergambar bahwa para pendeta kurang dalam melaksanakan beberapa fungsi pastoral, yakni

36 H. Rothlisberger, Homiletika, 20th ed. (Jakarta: BPK Gunung Mulia, 2006).

37 James Braga, How to Prepare Bible Messages, 35th ed. (Colorado: Multnomah Books, 2005), 183 184.

38 Aart Martin Van Beek, Pendampingan Pastoral (Jakarta: BPK Gunung Mulia, 2003), 12-15. membimbing, mendamaikan, menopang, menyembuhkan dan mengasuh. Fungsi-fungsi ini berguna untuk membangun potensi serta menumbuh-kembangkan kehidupan anggota jemaat sebagai kekuatan yang dapat diandalkannya untuk melanjutkan kehidupan. ${ }^{38}$ Namun pada kenyataannya pelaksanaan pendampingan dan konseling pastoral (pelayanan pribadi) kepada anggota jemaat yang menghadapi masalah dan duka cita oleh para pendeta BNKP belum optimal sebagaimana diharapkan.

Tujuan dilaksanakannya konseling bagi anggota jemaat: untuk mereka yang memiliki masalah-masalah yang tidak dapat mereka selesaikan atau yang mereka pikir tidak ada jalan keluarnya. Konseling merupakan sejenis pertolongan emosional, psikologis, yang disediakan untuk mereka yang menghadapi situasi-situasi hidup yang agak tidak wajar, dimana mereka mengalami sejumlah besar masalah. Meskipun keluarga, teman-teman, para pemuka agama mau pun masyarakat, bisa saja benar benar memberikan pertolongan, tetapi ada saat-saat dimana sumber pertolongan dari luar dibutuhkan. ${ }^{39}$

Penggembalaan/kunjungan atau konseling kepada anggota jemaat adalah suatu cara untuk menjawab kebutuhan setiap orang akan kehangatan, perhatian penuh, dukungan, dan pengarahan. Kebutuhan ini memuncak pada waktu tekanan pribadi dan kekacauan sosial terjadi. Layanan pastoral adalah ungkapan pendampingan yang bersifat memperbaiki yang berusaha membawa kesembuhan bagi orang yang sedang menderita gangguan fungsi dan kehancuran pribadi karena krisis. Pelayanan konseling jemaat mempunyai misi yang menjangkau baik ke dalam maupun ke luar, dimanapun orang membutuhkan pertolongan. ${ }^{40}$

\section{Pelayanan Pastoral Pra-babtis dan Perjamuan Kudus}

Layanan sakramen perjamuan kudus ditujukkan bagi orang-orang yang merasa lemah

39 Anthony Yeo, Konseling: Suatu Pendekatan Pemecahan Masalah (Jakarta: BPK Gunung Mulia, 1999), 137.

40 Howard Clinebell, Tipe-Tipe Dasar Pendampingan Dan Konseling Pastoral (Jakarta: BPK Gunung Mulia, 2002), 59-60. 
dan yang mencari kekuataannya dari Tuhan. Orang yang insaf akan kelemahannya seperti Rasul Paulus (Rm 7:13-26) yang merasa lemah di dalam imannya, itulah yang mendapatkan kekuasaannya dari Kristus. Perjamuan kudus itu bagi orang yang tidak memuliakan diri (sombong), pun juga tidak menghina sesamanya, melainkan memuliakan Tuhan Allah.

Dalam hal pelaksanaan penggembalaan pra-baptis dan persiapan perjamuan kudus, (dalam konteks BNKP: Sekola Wanekhego tõdõ), Tabel 1(3) menunjukkan bahwa pelaksanaannya belum merata di seluruh jemaat. Terdapat hanya 29 orang pendeta yang melaksanakan dengan baik dan sungguh-sungguh, sedangkan yang lainnya dilakukan selama ada waktu serta tidak terprogram dalam pelayanan jemaat. Yang menyedihkan justru ada 14 orang pendeta yang tidak memahami pentingnya penggembalaan prabaptis dan persiapan perjamuan kudus sehingga tidak dilaksanakan dalam pelayanan di jemaat.

Tabel 1(3) juga menunjukkan bahwa sebagian besar para pendeta belum melaksanakan tugasnya dalam melakukan prasakramen baik perjamuan kudus maupun baptisan kudus kepada warga jemaatnya. Hal ini akan berdampak dalam kehidupan iman warga jemaat, di mana warga mengikuti sakramen baik baptisan kudus maupun perjamuan kudus sebagai bentuk formalitas tanpa mengetahui apa arti dan makna yang sesungguhnya dari sakramen itu. Warga jemaat akan mengabaikan nilai-nilai sakramen yang dilayankan oleh gereja sebagai sarana penting dalam memelihara iman warga gereja.

\section{Pelayanan Pengajaran}

Salah satu tugas penting yang diberikan kepada pendeta adalah tugas pengajaran khususnya di Sekolah Sidi dan bagi anak-anak Sekolah Minggu. Sampai sekarang pada hampir semua jemaat di BNKP, yang paling kompeten untuk melakukan pengajaran iman Kristen adalah para pendeta. Memang harus diakui bahwa jauh lebih baik apabila di dalam jemaat diangkat seorang guru dari latar belakang pendidikan agama Kristen, namun karena keterbatasn dana yang dipunyai gereja maka tugas ini diberikan kepada pendeta.

Pengajaran agama Kristen khususnya bagi anak-anak Sekolah Minggu dan Sekolah Sidi merupakan tugas utama dalam rangka mempersiapkan anggota jemaat memahami inti pengajaran Kristen. Malalui ini pula mereka dapat memperoleh kesempatan untuk mengenal Tuhan dengan lebih baik sehingga membawa dampak pada perobahan tingkah laku dan cara berpikir anggota Jemaat.

Dalam hal pengajaran ini, terlihat bahwa tugas ini belum sepenuhnya dilaksanakan oleh para pendeta baik yang ada di jemaat maupun yang di resort. Justru yang paling banyak mengajar adalah para Satua Niha Keriso (SNK). Tentu dengan pengetahuan yang sangat terbatas yang dimiliki oleh para SNK akan berpengaruh pada kualitas pengajaran yang akan diberikan kepada anggota jemaat. Tabel 1(4) menunjukkan bahwa dari 60 partisipan, hanya 20 orang Pendeta yang benar-benar menunaikan tugas ini dengan baik, Artinya mereka melakukannya sebagai bagian dari tugas dan tanggungjawab mereka sebagai pendeta di jemaat. 33 orang hanya melaksanakannya menurut jadwal (sekali dalam sebulan). Terdapat 7 orang yang sama sekali tidak melakukan pengajaran ini dan menyerahkannya kepada para SNK atau guru pengajar yang dihujuk untuk itu.

\section{Kepemimpinan dalam Jemaat}

Untuk melihat tingkat efektifitas kepemimpinan pendeta di jemaat, peneliti menggunakan 8 (delapan) indikator penilaian yang merupakan prinsip-prinsip dasar keberhasilan seorang pemimpin, yakni (a) integritas, (b) kebaikan, (c) kepercayaan, (d) pertumbuhan, (e) kasih, (f) sukacita, (g) keunggulan dan (h) sukacita.

Tabel 1(4) menunjukkan bahwa terdapat 28 orang $(47,67 \%)$ pendeta memiliki kualitas kepemimpinan dengan kategori tinggi sebagaimana indikator penilaian di atas. 16 orang $(26,67 \%)$ di antaranya tergolong sedang, yakni pendeta yang menjalankan kepemimpinan dan pelayanannya sebagai sebuah rutinitas tanpa inovasi dan evaluasi untuk menciptakan hal-hal yang baru bagi pelayanan jemaat. Ini juga terlihat dalam sikap dan karakter pendeta yang kurang memberi pengaruh baik kepada sesama pelayan atau anggota jemaat. Kehadiran pendeta di tengah jemaat tidak menghadirkan angin segar yang mendorong jemaat semakin berkembang. Pendeta dengan kepemimpinan berkualitas rendah juga cukup memrihantinkan, berjumlah 6 
orang $(26,6,7 \%)$. Informasi dari beberapa orang tokoh dan pelayan jemaat di tempat di mana pendeta ini melayani, menjelaskan bahwa yang bersangkutan tidak menunjukkan pola kepemimpinan sebagai orang yang rendah hati, arogan, kurang disiplin, suka memilih-milih, pemarah dan kurang bijaksana dalam mengambil keputusan.

\section{Persekutuan Jemaat}

Umumnya Jemaat-jemaat BNKP berada di lingkungan desa-desa di Kepulauan Nias. Hal ini berbeda dengan jemaat-jemaat di pulau Sumatera dan Jawa. Jemaat yang berada di perkotaan baik kota propinsi, kabupaten dan kota, warga jemaat menyebar dan tidak saling berdekatan satu sama lain. Atau jemaat yang berada di perkebunan-perkebunan tentu saja hidup berbaur dengan karyawan lain di perkebunan. Sehingga persekutuan antar anggota jemaat dalam melaksanakan kegiatan gerejawi tidak sebaik yang ada di desa-desa di kepulauan Nias. Karena lokasi penelitian dipusatkan di Kepulauan Nias, maka persekutuan Jemaat yang dilihat di sini adalah upaya-upaya yang dilakukan pendeta kepada anggota jemaat memupuk persekutuan satu dengan yang lain dalam konteks menyukseskan program pelayanan gereja.

Hakikat persekutuan adalah terbinanya relasi antar pelayan dengan warga gereja dan antar warga gereja satu dengan yang lain. Dalam hubungan dengan pendeta, mesti dilihat apakah warga jemaat melihat pendeta sebagai teman yang memerhatikan, berbagi suka-duka dan hidup bersama mereka. Cara pandang jemaat dan pendeta satu sama lain bergantung pada relasi yang terjalin diantara mereka. Ini penting karena pendeta tidak bisa melayani secara optimal tanpa relasi yang baik dengan warga gereja. Banyak masalah dijemaat diputuskan berdasarkan cinta kasih dan relasi yang baik serta kepercayaan kepada pendeta. Bagaimana relasi ini dibangun, semuanya terjadi bila pendeta peduli dan memperhatikan serta hadir dalam pergumulan-pergumulan anggota jemaat.

Mengenal satu sama lain secara pribadi dan berbagi pengalaman hidup untuk membangun

${ }^{41}$ Joe E. Trull et al., Etika Pelayan Gereja: Peran Moral Dan Tanggung Jawab Etis Pelayan Gereja (Jakarta: BPK Gunung Mulia, 2015), 126. persekutuan dalam gereja, dilakukan dengan perhatian dan bela rasa serta kepedulian yang sungguh-sungguh dimana pendeta melihat bahwa anggota jemaat adalah orang-orang yang berarti dan penting, semua ini ditentukan oleh integritas pendeta. Namun persekutuan tidak akan terjadi apabila pendeta melayani anggota jemaat dengan pendekatan kekuasaan. Samuel Southard sebagaimana dikutip Trull dan Carter, mengatakan bahwa pelayan harus melakukan beberapa hal antara lain melestarian nilai-nilai tradisional; peka terhadap perasaan pribadi dan relasi komunitas untuk menggerakan gereja mencapai target-target tertentu; serta pengaruh terhadap hidup warga jemaat sehingga mereka dan dunia tempat hidup mereka mungkin berpaling kepada Allah. ${ }^{41}$

Data pada Tabel 1(6) menunjukkan bahwa dari 60 orang pendeta, terdapat $32(35 \%)$ pendeta yang dapat membangun persekutuan dengan baik di tengah-tengah jemaat dengan menjaga relasi yang baik kepada anggota jemaat, mengenal jemaat dengan baik serta peduli akan persoalan-persoalan hidup mereka. Di samping itu, mereka juga dapat menyesuaikan diri dengan kenyataan berbagai kondisi (tradisi) yang ada di mana jemaat hidup. Dengan persekutuan yang baik ini, terlihat bila jemaat ini tidak hidup berkonflik dengan pendeta dan persekutuan antar jemaat akrab dan saling memmerhatikan. Namun pada sisi lain terdapat 15 orang pendeta, yang belum optimal membangun relasi dengan jemaat. Pendeta kurang dekat dengan jemaat dan anggota jemaat kurang mengenal pendeta secara mendalam. Di samping itu terdapat rasa ketidakpuasan atas berbagai keputusan dan sikap pendeta yang kurang memedulikan keluhan-keluhan jemaat.

Tabel 1(6) juga menyisakan 13 orang pendeta yang tidak bisa membangun persekutuan dengan jemaat yang ia layani. Hal ini nampak jelas dimana banyak terjadi konflik terhadap pendeta serta tidak harmonisnya hubungan antar anggota jemaat. Kondisi kehidupan jemaat kurang mencerminkan kehidupan kekristenan yang baik bahkan seperti ada permusuhan yang tak habis-habisnya baik antar pendeta dengan anggota jemaat maupun antar anggota jemaat sendiri. Kondisi ini 
menyebabkan program pelayanan tidak berjalan baik dan pembinaan iman anggota jemaat mengalami kemunduran. Dalam kitab Efesus 4:27 mengingatkan kita bahwa "Hendaklah kamu selalu rendah hati, lembah lembut dan sabar. Tunjukkan kasihmu dalam hal saling membantu. Dan berusahalah memelihara kesatuan Roh oleh ikatan damai sejahtera. Satu tubuh dan satu Roh sebagaimana kamu telah dipanggil kepada satu pengharapan yang terkandung dalam pnggilanmu. Satu Tuhan, satu Iman, satu Baptisan, satu Allah dan Bapa dari semua Allah yang di atas semua dan oleh semua dan di dalam semua. Tetapi kepada kita masing-masing telah dianugerahkan kasih kerunia menurut ukuran pemberian Kristus."

\section{Pendeta dan Sosial-Ekonomi Jemaat}

Bidang program pelayanan Diakonia yang holistik adalah pelayanan untuk membebaskan manusia dari segala kemiskinan, kebodohan, kemelaratan, segala penyakit, ketidakadilan dan segala bentuk keterbelakangan dalam masyarakat, sebagaimana dilakukan oleh Yesus Kristus (Mat. 4:24; Luk. 4:18-19). Tugas panggilan ini diarahkan pada upaya BNKP menjadi berkat dalam dunia ini melalui kegiatan pendampingan terhadap mereka yang terabaikan, pemberantasan kemiskinan dan keterbelakangan melalui pemberdayaan dan pengembangan masyarakat, perjuangan keadilan dan hak-hak azasi manusia, memperjuangkan keadilan jender, memberi landasan etis dan moral dalam pembangunan bangsa, dan ikut dalam pemeliharaan lingkungan dan alam ciptaan Allah. Hal ini merupakan tugas pelayanan yang harus diemban pendeta agar masyarakat dapat merasakan kehadiran gereja.

Pada sisi yang lain pendeta juga bertanggungjawab dalam bidang penatalayanan keuangan dan harta milik yang ada di jemaat atau yang dikenal dengan istilah oikonomia, serta upaya-upaya pemandirian dana di BNKP, melalui penataan sistem persembahan dan keuangan, penataan dan pemanfaatan aset-aset yang dimiliki oleh BNKP, penggalangan dana abadi, serta peningkatan sistem jejaring - yang semuanya diarahkan untuk menunjang pelayanan dalam rangka mencapai visi dan misi BNKP.

${ }^{42}$ Wawancara dengan beberapa tokoh warga, tanggal 12 Mei 2016.
Tanggungjawab kearah ini oleh 60 orang pendeta BNKP belum menjadi perhatian dan justru sangat diabaikan (Tabel 1.7). Hanya 11 orang pendeta yang peduli akan kehidupan sosial dan ekonomi gereja serta tanggungjawab dalam menata keuangan jemaat, 15 orang melaksanakannya dengan sikap biasa-biasa saja dan terdapat 34 orang yang kurang memperdulikannya. Dalam beberapa keterangan yang diberikan oleh responden di jemaat khususnya bagi para pendeta yang tidak peduli dengan kehidupan sosial dan ekonomi jemaat mengatakan bahwa umumnya pendeta hanya mengurusi persoalan kerohanian jemaat melalui khotbah dalam berbagai ibadah jemaat dan kurang memberi motivasi apalagi mau terlibat langsung dengan kehidupan sosial ekonomi. Hal itu dapat terlihat dari tidak adanya program jemaat yang bersentuhan dengan persoalan sosial-ekonomi baik yang bersifat pelatihanpelatihan maupun program pengembangan langsung dibidang pekerjaan yang ditekuni anggota jemaat. ${ }^{42}$

Beberapa responden juga mengatakan bahwa pendetanya kurang memiliki keterampilan dalam penataan adminisrasi dan keuangan sehingga penyelenggaraan administrasi dan keungan jemaat menjadi kacau dan jarang ada pertanggungjawaban pelayanan secara baik di dalam sidang-sidang majelis jemaat. ${ }^{43}$

\section{Kedisiplinan Pendeta dalam Pelayanan}

Pendeta yang disiplin adalah pendeta yang selalu setia dalam menjalankan tugas pelayanan. BNKP adalah suatu gereja dimana ia telah melakukan pemanggilan, penerimaan dan penahbisan terhadap pendeta untuk melayani anggota-anggota gereja. Banyak di antara pendeta BNKP yang setelah menjadi pendeta lalu mencari tambahan pekerjaan lain menjadi guru di beberapa sekolah atau terlibat dalam komisi pemilihan Umum (KPU) atau panitia pengawas dalam pemilihan umum. Pada sisi lain ada juga beberapa pendeta yang lebih rajin berkhotbah di tempat lain dan tidak peduli dengan keadaan di jemaatnya. Ada lagi yang hanya pergi ke jemaatnya pada setiap hari Minggu dan seterusnya ia tinggal di rumahnya yang jauh dari jemaat tempat ia melayani. Ditemukan juga

$$
{ }^{43} \text { Ibid. }
$$


bahwa ada beberapa orang pendeta yang menyusun program pelayanannya sebagai suatu syarat saja untuk memenuhi tuntutan organisasi dan seterusnya program itu tidak pernah dijalankan dengan baik apalagi mau melakukan evaluasi terhadap pelaksanaannya. Semua kegiatan pelayanan dilaksanakan hanya rutinitas saja menurut apa yang diperlukan di saat itu dan bukan berdasarkan perencanaan sebelumnya.

Dari data penelitian pada Tabel 1(8) memberi gambaran bagaimana kedisiplinan pendeta. Terdapat 28 orang pendeta yang memiliki disiplin tinggi dan 15 orang sedang dan 17 orang yang sangat rendah. Data ini menunjukkan tingkat kesetiaan pendeta dalam menjalankan tugas pelayanan. Lebih setengah para pendeta yang kurang berdisiplin dalam pelayanan. Hal ini bisa berakibat pada kualitas pelayanan pendeta di jemaat. Artinya komitmen pendeta untuk melakukan pelayanan dengan penuh integritas sangat menentukan. Pendeta kurang berdisiplin menjalankan panggilannya dari Tuhan. Bahkan ada pendeta BNKP tidak memahami dirinya sebagai orang-orang pilihan yang dipanggil untuk tugas khusus seperti halnya Abraham utuk memimpin suatu umat baru dan menjadi berkat bagi bangsa-bangsa (Kej 12:1-3), atau seperti Musa yang dipanggil dan diutus menjadi pembebas bagi umat Israel (Kel 3:10), atau tanggapan dari pemanggilan Yesaya yang mengatakan "Inilah aku utuslah" aku ( Yes. $6: 8$ ).

\section{Spiritualitas dan Integritas Pendeta}

Spiritualitas adalah aspek terpenting dalam kehidupan pendeta. Sebagai pelayan Kristus, spiritualitas pendeta berakar pada spiritualitas Kristus dan menjadi ciri semua spiritualitas Kristen. Sheldrake dalam Lase (2020) mendefinisikan spiritualitas "the conscious human response to God that is both personal and ecclesial." 44 Dengan demikian spiritualitas menjadi landasan kehidupan pribadi maupun jabatan pelayanan yang diemban seorang pendeta. Sebagai pemimpin tentu spiritualitas seorang pendeta

${ }^{44}$ Delipiter Lase and Etty Destinawati Hulu,

"Dimensi Spritualitas Dalam Kompetensi Kepribadian Guru Pendidikan Agama Kristen," SUNDERMANN Jurnal Ilmiah Teologi Pendidikan Sains Humaniora dan Kebudayaan (2020). melebihi atau di atas rata-rata spiritualitas anggota jemaat, kalau tidak demikian ia tidak mungkin menjadi pemimpin atau pelayan rohani bagi mereka.

Inti dari spiritualitas adalah pemaknaan hidup dan tujuannya, peran kita di dalamnya, makna keberadaan orang lain bagi kita dan kedekatan dan keintiman kita dengan Tuhan pencipta. ${ }^{45}$ Bagaimana seorang pendeta membina hubungan dengan jemaat dan sesama pelayan dalam Jemaat dan memberi tempat bagi siapa saja untuk ikut berperan dalam penyelenggaraan pelayanan merupakan indikator bahwa pendeta tersebut memiliki nilainilai spiritualitas yang baik. Selanjutnya Borong mengatakan bahwa Spiritualitas berkaitan dengan ibadah dan Keterlibatan hidup dengan sesama yakni berbuat keadilan dan kebajikan serta keterlibatan dalam pelayanan sosial. ${ }^{46}$

Spiritualitas adalah kehidupan yang berkualitas sebagai wujud ungkapan syukur atas keselamatan. Dengan demikian hidup yang berkwalitas itu selalu terarah pada kebaikan pribadi maupun kebaikan sesama. Spiritualitas seorang pendeta adalah sumber kepercayaan anggota jemaat kepada pendeta. Kalau pendeta tidak bisa menunjukkan kehidupan rohani yang memadai, maka jemaat tidak akan mempercayai apa yang akan dikatakan oleh pendeta karena tidak sesuai dengan kehidupan pendeta itu sendiri. Pada akhirnya Spirituaitas pendeta akan membangun Integritas pribadinya. Segala perkataanya bermuara pada apa yang dilakukannya. Kehidupan Spiritualitas pendeta dinyatakan dalam keakraban pendeta dengan Tuhan Allah dan firmannya melalui kesetiaan berkomunikasi dengan Allah dalam doa, membaca Alkitab dan merenungkannya serta mempraktekkannya dalam tindakannya seharihari. Itulah ciri spirulitas pendeta dan sekaligus sumber kekuatannya.

Spiritualitas menumbuhkan integritas. Integritas itu berarti suatu prbadi yang bisa dipercaya, karena ia konsisten dan bertanggungjawab. Integritas pendeta sangat

${ }^{45}$ Robby I Chandra, Berani Jadi Kacung: Kamu Juga Bisa Melayani (Jakarta: Grafika Kreasindo, 2014), 71.

${ }^{46}$ Robert P. Borrong, Melayani Makin Sungguh - Siknifikansi Kode Etik Pendeta Bagi Pelayanan GerejaGereja Di Indonesia (Jakarta: BPK Gunung Mulia, 2016), 86. 
ditentukan oleh imannya. Tanpa integritas, pekerjaan pelayanan pendeta akan sia-sia dan gagal. Seorang pendeta yang memiliki integritas iman, juga memiliki integritas intelektual dan integritas moral. Hal ini nampak dalam pola hidup pendeta yang menunjukkan sikap rendah hati, hidup secara bersih dan tetap setia melayani Tuhan di mana ia ditempatkan.

Data pada tabel 1(9) menunjukkan 34 orang pendeta yang boleh dikatakan memiliki spiritualitas dan integritas yang baik di tengahtengah jemaat. Hal itu diakui banyak oleh anggota jemaat di mana pendeta tersebut melayani. Namun di sisi lain, terdapat 16 orang pendeta dengan derajat spiritualitas dan integritas yang bisa-biasa saja, artinya pola hidupnya sama saja dengan pola hidup yang ditunjukkan anggota jemaatnya. Ia tidak punya nilai lebih sehingga ia belum menjadi pola anut utama bagi jemaat. Jemaat masih ragu-ragu akan nilai spiritulias dan integritasnya. Yang memprihatinkan ialah dari 60 orang pendeta BNKP yang diteliti terdapat 10 orang dengan derajat spiritualitas dan integritas yang rendah. Menurut wawancara dengan tokoh jemaat di tempat di mana pendeta melayani, pendeta kurang bisa dipercaya, karena kurang rendah hati dan sering hanya membicarakan gaji dan kebutuhannya saja. Suka mengeluhkan keadaan di jemaat dan sering memihak hanya kepada anggota jemaat yang ia sukai dan menyukai dia. Ia tidak hadir sebagai seorang pemimpin yang di hormati tapi lebih sebagai pembawa masalah di tengah jemaat.

\section{Faktor-faktor yang Memengaruhi Etos Kerja Pendeta di BNKP}

Berdasarkan hasil wawancara dan observasi di jemaat dan resort terlihat beberapa faktor yang mempengaruhi etos kerja pendeta $\mathrm{BNKP}$, adalah sebagai berikut.

\section{Krisis Panggilan \& Kekaburan Tanggung Jawab}

Merupakan pemahaman umum bahwa kesediaan menjadi pendeta adalah bentuk tanggapan atas panggilan dari Tuhan sendiri. Kejelasan atas panggilan menentukan sikap etis pendeta. Lunturnya rasa terpanggil merupakan akar dari disorientasi moral para pendeta. Teologi Protestan memang meyakini panggilan sebagai konsep yang tidak terbatas pada profesi pendeta, melainkan terkait pada semua pekerjaan yang membangun masyarakat. Ini tidak dimaksudkan untuk menyangkali atau mereduksi makna pangggilan kependetaan.

Kekeliruan memahami konsep panggilan mempunyai implikasi langsung dalam hubungan etos kerja. Padahal panggilan Tuhan bukanlah hanya fenomena batin, tetapi juga peristiwa gerejawi yang melibatkan persekutuan orang percaya di mana pendeta akan melayani di tengah-tengah mereka. Panggilan pendeta (vocatio) adalah sebagai pemberita atau juru bicara Allah. Rasul Paulus memahami dirinya dipanggil menjadi rasul sejak dalam kandungan." Tetapi waktu Ia yang telah memilih aku sejak kandungan ibuku, dan memanggil aku oleh kasih karunia-Nya di dalam aku, supaya aku memberitakan Dia diantara bangsa-bangsa bukan Yahudi, maka sesaat pun aku tidak minta pertimbangan kepada manusia" (Gal. 1:15-16). Demikian juga para pendeta BNKP harus yakin pada rencana Allah dan meyakinkan dirinya sebagai orang-orang pilihan yang dipanggil untuk tugas khusus, seperti Abraham memimpin suatu umat baru untuk menjadi berkat bagi bangsa-bangsa (Kej 12:1-3), atau seperti Musa yang dipanggil khusus untuk diutus menjadi pembebas bagi umat Israel (Kel. 3:10), atau jawaban atas pemanggilan Yesaya: "Inilah Aku utuslah aku" (Yesaya 6:8).

Dengan keyakinan ini maka pendeta BNKP seharusnya menjadi pelayan yang membawa perubahan pada kehidupan anggota jemaat. Bahkan berkarya seperti para malaikat yang membawa kabar baik yang dapat mengubahkan kehidupan orang-orang yang mendengarnya menjadi orang-orang hidup secara baik dan benar di hadapan Allah. Untuk memperbaiki kinerja pendeta di BNKP perlu belajar delapan model pelayanan pendeta sebagaimana dijelaskan oleh dari Carnigie Samuel Calian dalam Robert P. Borrong, yakni (1) Gembala yang menghamba (2) Nabi - yang politisi (3) Guru - yang berkhotbah (4) Penginjil Kharismatik (5) Promotor - Pragmatis (6) 
Menejer - Penyemangat (7) Pemimpin Liturgi yang merayakan (8) Penasihat - yang melayani. ${ }^{47}$

Pendeta BNKP harus lebih profesional dalam pelayanan, memiliki kecakapan yang bernilai tinggi dan memiliki karakter, integritas diri, komitmen, kompetensi serta disiplin yang membedakan dirinya dari pekerja biasa. Inilah nilai yang harus dibenahi kepada para pendeta. Bertolak dari data yang ada, maka dalam hubungan dengan peningkatan etos kerja pendeta di BNKP, penulis hendak mengemukakan beberapa hal yang perlu dimiliki oleh pendeta BNKP dalam pelayanan di antaranya: 1) Pendeta BNKP perlu meningkatkan kompetensi dan keahlian dibidang pemberita-an firman Tuhan (khotbah), konseling pastoral, pengajaran dan kepemimpinan; 2) membangun kembali komitmen terhadap panggilannya sebagai pendeta dan profesinya, bukan mendasarinya pada imbalan uang dan harta; dan 3) meningkatkan prestasi untuk mempertahankan pelayanan di tengah rumitnya kondisi kehidupan sekarang ini.

\section{Spiritualitas dan Integritas Pendeta}

Spirituaitas merupakan aspek penting dalam kehidupan pendeta. Spiritualitas menjadi landasan kehidupan pribadi maupun jabatan pelayanan yang diemban seorang pendeta. Sebagai pemimpin, diharapkan bahwa spiritualitas seorang pendeta melebihi atau di atas rata-rata spiritualitas anggota jemaat yang dipimpinnya, jika tidak demikian ia tidak mungkin menjadi pemimpin dan pelayan rohani bagi mereka.

Berbicara tentang spiritualitas adalah berbicara tentang diri pendeta secara utuh dan menyeluruh baik tubuh (soma), jiwa (psukhe), dan roh (pneuma). Ketiga unsur ini tidak ada yang lebih tinggi atau mulia sebab ketiganya hendak menunjukkan bahwa manusia itu makhluk hidup. Manusia tidak hanya memelihara hidup rohani dan mengabaikan hidup jasmani atau jiwa. Jadi dalam hal spiritualitas, para pendeta BNKP tetap membina

47 Borrong, Melayani Makin Sungguh - Siknifikansi Kode Etik Pendeta Bagi Pelayanan Gereja-Gereja Di Indonesia.

48 Pusat Bahasa, "Kamus Besar Bahasa Indonesia," Kementerian Pendidikan Dan Budaya.

49 Anugerah Pekerti and Jansen H. Sinamo, Kompetensi Etis Dan Spiritual, Keniscayaan Pemimpin hubungan khusus dengan Tuhan, mengosongkan diri dan menguduskannya secara penuh. Hidup seperti itulah yang dituntut dari seorang pendeta.

Pendeta tidak hanya berkhotbah tentang kasih, keadilan, kesabaran dan pembebasan sementara ia sendiri jauh dari hal-hal yang ia khotbahkan. Dalam khotbah, berita firman Tuhan haruslah lebih dulu dihidupi oleh seorang pendeta sehingga dari cara hidup yang ia tunjukkan itu anggota jemaat belajar mengikutinya. Nilai-nilai spiritualitas yang mesti ditumbuhkan oleh pendeta di BNKP meliputi pertobatan, hidup saleh, moralitas yang baik, integritas diri dan karakter yang membangun. Pendeta yang berspiritualitas adalah pendeta yang selalu aktif dalam kegiatan-kegiatan sosial yang ada ditengah-tengah jemaatnya.

Penulis melihat bahwa integritas pendeta di BNKP juga perlu dikembangkan lagi. Integritas berasal dari bahasa Latin, Integrate yang artinya membuat untuk/menyatu. Dalam kamus besar bahasa Indonesia, integritas diartikan sebagai keterpaduan, kebulatan, keutuhan, jujur dan dapat dipercaya. ${ }^{48}$ Dengan pengertian ini berarti pendeta BNKP harus memiliki keutuhan yakni satunya kata dengan perbuatan, jujur dan dapat dipercaya. Ia adalah satu dalam hati, pikiran, kehendak dan tindakan.

Pendeta yang mempunyai integritas atau jati diri adalah orang yang memandang diri sebagai mitra dari orang yang dipimpinnya. Ia tidak memperlakukan orang lain sebagai bawahan tetapi sebagai rekan untuk mencapai tujuan bersama. ${ }^{4950}$ Pemimpin seperti ini menciptakan ruang bagi orang lain untuk mengembangkan kreatifitas agar dapat berprestasi, serta menciptakan harapan bersama untuk saling memberdayakan.

Pendeta sebagai Pemimpin gerejawi harus mendasari diri pada teladan kepemimpinan Tuhan Yesus yang melakukan pembaharuan melalui pelayanan dan bukan dengan menggunakan kuasa (bdg. Markus 10:45); Yesus tidak menganggap kuasa yang ada padaNya

Abad Ke-21 (Jakarta: Unit Publikasi dan Informasi STT Jakarta, 2001).

${ }^{50}$ Ferdinand Suleeman, Adji Ageng Sutama, and A. Rajendra, eds., Struggling in Hope: A Tribute to the Rev. Dr. Eka Darmaputera, 1st ed. (Jakarta: BPK Gunung Mulia, 1999), 755. 
sebagai milik yang harus dipertahankan. Kuasa itu justru dipergunakan untuk membangun relasi dengan murid-muridNya sambil menunjukkan rasa tanggungjawab untuk melakukan segala sesuatu dengan penuh pengorbanan. Hal mana integritas ini dipraktekkan melalui ketulusan, kebenaran, kesetiaan dan kemurnian hati. Semua ini harus dilakukan dengan bersumber pada kasih Allah dan bukan dari hikmat duniawi (bdg. 1 Raja-raja 9:4-5; 2 Kor1:12). Hikmat dari allah mengandung dimensi kesalehan, kejujuran dan tidak mencari muka. Dalam Surat Titus 2:7-8, Paulus menasihatkan Titus dengan mengatakan: "Jadikanlah dirimu sendiri suatu teladan dalam berbuat baik, hendaklah engkau jujur dan bersungguh-sungguh dalam pengajaranmu, sehat dan tidak bercela dalam perbuatanmu, sehingga lawan menjadi malu karena tidak ada hal-hal buruk yang mereka sebarkan tentang kita."

\section{Kepemimpinan}

Hasil pengamatan dan wawancara menggambarkan bila pertama, masih ada pendeta yang kurang peduli/prihatin atas berbagai persoalan nyata yang dihadapi anggota jemaat, misalnya masalah pendidikan, kesehatan atau masalah penyakit sosial seperti minuman keras, judi dan lain yang dapat berpengaruh langsung pada kesejahteraan hidup anggota jemaat. Kedua, pendeta yang tidak bisa menjadi inspirasi/ motivator bagi anggota jemaat karena pola hidup pendeta yang cenderung malas, kurang disiplin, emosional, baik pelayanan maupun pola hidup yang ditunjukkan setiap hari. Ketiga, pendeta dan keluarganya belum menunjukkan sifat keteladanan yang baik di tengah-tengah jemaat maupun dalam pelayanan. Empat, Pendeta kurang melakukan pendidikan karakter bagi anak-anak remaja-pemuda di jemaat dan resort. Terakhir, pendeta kurang melakukan perkunjungan terhadap anggota jemaat, bahkan cenderung menutup diri.

Kondisi-kondisi tersebut, menyebabkan etos kerja pendeta menjadi tidak memadai dan kurang mendapat dukungan bagi rekan pelayan

51 J. Oswald Sanders, Spiritual Leadership: Principles of Exellence for Every Believer (Chicago: Moody Publishers, 2007), 25.

52 Chandra, Berani Jadi Kacung: Kamu Juga Bisa Melayani. lain dan semua anggota jemaat. Dalam kondisi ini pendeta perlu BNKP belajar tentang kepemimpinan yang menghamba, artinya selalu memiliki kesadaran bahwa menjadi pendeta adalah melayani dan bukan berkuasa dan mencari keuntungan. Dengan pola kepemimpinan hamba, warga jemaat akan mengalami berkat melalui pelayanan pendeta dan pada sisi yang lain pendeta akan diberkati oleh karena pelayanan dan kepemimpinannya yang baik.

Inti dari kepemimpinan adalah bagaimana mempengaruhi orang lain. ${ }^{1}$ Untuk mempengaruhi orang lain, seorang pemimpin harus memiliki kelebihan-kelebihan di dalam pekerjaannya. Kelebihan-kelebihan tersebut diakui, diterima dan menghasilkan kepercayaan serta dukungan nyata dari orang-orang. ${ }^{52}$ Dalam konteks masyarakat Nias, pemimpin adalah seseorang yang memiliki kapasitas (kecerdasan) dan integritas (peduli terhadap rakyat, mengayomi dan melayani rakyat), sehingga terhormat di tengah-tengah masyarakat. ${ }^{53}$

Dengan demikian organisasi di mana ia bekerja akan memberikan kepercayaan/ wewenang tambahan, teman kerjanya akan memberi dukungan dan orang-orang yang dipimpinnya akan bersedia mengikutinya. Mengacu pada pendapat Robby Candra d iatas, maka yang perlu dilakukan oleh pendeta BNKP dalam menjalankan kepemimpinan baik di jemaat maupun resort adalah:

a) Memiliki kompetensi umum dan spesifik dalam hal pengembangan sumber daya manusia, mengingat warga jemaat BNKP umumnya berada di pedesaan dan memiliki tingkat pendidikan dan keterampilan yang sangat rendah. Di sini para pendeta berperan untuk meningkatkan sumber daya jemaat dengan membagikan kelebihan-kelebihan yang dimiliki.

b) Menjadi sumber inspirasi dan motivasi dalam mengembangkan nilai-nilai sosial budaya, baik aspek jasmani maupun hidup rohani mereka.

c) Menjadi guru/pengajar yang terampil bagi anggota jemaat, khususnya dalam hal

53 Tuhoni Telaumbanua, "Kaum Milenial \&amp; Kebudayaan Nias," SUNDERMANN Jurnal Ilmiah Teologi Pendidikan Sains Humaniora dan Kebudayaan 1, no. 1 (October 2019): 1-16. 
pengajaran Sekolah Minggu, Sidi dan penelaahan Alkitab.

d) Memiliki visi yang jelas dan dapat dilaksanakan di jemaat atau resort yang dipimpinnya.

e) Membangun relasi yang intim kepada semua rekan pelayan dan anggota jemaat untuk mewujudkan harapan bersama membangun kehidupan yang lebih baik.

\section{Perbedaan Latar Belakang Pendidikan Teologi}

Perbedaan latar belakang teologi juga sering menimbulkan masalah dalam pelayanan pendeta di jemaat-resort. Polarisasi antara kubu evangelical/konservatif/fundamentalis dan ecumenical/liberal/kontekstual telah merusak persatuan dan pelayanan. Berangkat dari paradigma teologis yang berbeda, pendetapendeta yang berbeda latar belakang teologinya seringkali membingungkan jemaat karena saling bertentangan dalam pendekatan pastoral, sikap etika sosial, dan konsep kepemimpinan. Ketegangan bisa meruncing apabila salah satu pihak atau kedua-duanya memainkan peran sebagai duta atau agen dari sekolah teologi yang menjadi almamater mereka, dengan misi 'menduduki' atau 'memonopoli' gereja di mana mereka melayani, baik pada lingkup jemaat maupun resort dan sinodal.

Keterbatasan pengetahuan Teologi sebagian besar anggota jemaat merupakan faktor yang memudahkan jemaat dimobilisasi untuk mendukung atau mendepak setiap pendeta dengan latar belakang teologis tertentu. Hal ini suatu kenyataan bahwa para pendeta BNKP datang dari berbagai latar-belakang teologi baik yang Luteran, Calvinis, kharismatik bahkan dan beberapa dari aliran Teologi Pentakosta. Perbedaan latar belakang teologi dapat menjadi modal dasar dalam pelayanan kalau pendeta terus-menerus belajar agar ia semakin akurat membaca perubahan, mengantisipasi masa depan, dan mempengaruhi serta menggerakkan umat yang dipimpinnya. Yang dibutuhkan adalah seminar-seminar bagi para pendeta yang mencakup bidang teologi, pelayanan pastoral dan pengajaran-pengajaran yang sesuai dengan Alkitab. Keragaman latar belakang pendidikan teologi dapat mempengaruhi paradigma dalam memahami, merumuskan dan menjabarkan program bersama, baik menyangkut teologi maupun pelayanan masyarakat lainnya.

\section{KONKLUSI}

Hasil pengolahan data dan analisis, memberi informasi bahwa etos kerja pendeta dalam pelayanan di BNKP masih belum optimal, sebagian besar para pendeta melaksanakan tugas pelayanan sebagai rutinitas belaka tanpa terobosan dan inovasi. Hal itu terjadi hampir di semua aspek pelayanan baik dalam mempersiapkan khotbah yang baik, perkunjungan rumah tangga, pelaksanaan sakramen, pengajaran dan kepemimpinan.

Karena itu, beberapa hal yang mendesak untuk dilakukan dalam menangani etos kerja yang tidak maksimal ini adalah antara lain pertama, menyusun standar mutu dan prosedur operasional rekrutmen calon-calon pendeta di BNKP yang meliputi latar belakang teologi, komitmen, motivasi, integritas dan spiritualitas. Kedua, Melakukan pelatihan dan pembinaan yang terencana, terpadu dan berkelanjutan terhadap para pendeta di jemaat dan resort guna meningkatkan kualitas kepemimpinan dan profesionalitas pelayanan. Ketiga, membina para pendeta yang telah kehilangan motivasi dalam menjalankan tugas dan pelayanan. Keempat, membenahi sistem pengawasan dalam organisasi BNKP dengan membentuk elemen yang dapat memantau pelayanan pendeta di jemaat dan resort, dan terakhir adalah menerapkan kode etik pendeta dalam pelayanan baik jemaat maupun resort.

\section{ACKNOWLEDGMENT}

\section{REFERENSI}

Anoraga, Pamdji. Psikologi Kerja. Jakarta: Rineka Cipta, 2001.

Ayuningtyas, Liya Febriana. "Pengaruh Iklim Organisasi Terhadap Etos Kerja Karyawan..." Universitas Muhammadiyah Purwokerto, 2011.

Babbie, Earl R. "The Practice of Social Research Earl R. Babbie - Google Kitaplar." Cengage Learning.

Bahasa, Pusat. "Kamus Besar Bahasa Indonesia." Kementerian Pendidikan Dan Budaya.

Beek, Aart Martin Van. Pendampingan Pastoral. Jakarta: BPK Gunung Mulia, 2003.

Bernard, H. Russell. Research Methods in 
Anthropology: Qualitative and Quantitative Approaches. Walnut Creek: AltaMira Press, 1995.

Bernard, H Russell. Reserach Methods in Anthropology - Qualitative and Quantitative Approaches. AltaMira Press, 2006.

Borrong, Robert P. Melayani Makin Sungguh Siknifikansi Kode Etik Pendeta Bagi Pelayanan Gereja-Gereja Di Indonesia. Jakarta: BPK Gunung Mulia, 2016.

Bowker, Lee H., Robert Bogdan, and Steven J. Taylor. "Introduction to Qualitative Research Methods: A Phenomenological Approach to the Social Sciences." Teaching Sociology (1978).

BPMS-BNKP. "Peraturan Banua Niha Keriso Protestan Nomor 04/BPMS-BNKP/2008 Tentang Jemaat Di BNKP." Gunungsitoli: LPLG-BNKP, 2008.

Braga, James. How to Prepare Bible Messages. 35th ed. Colorado: Multnomah Books, 2005.

Chandra, Robby I. Berani Jadi Kacung: Kamu Juga Bisa Melayani. Jakarta: Grafika Kreasindo, 2014.

Clinebell, Howard. Tipe-Tipe Dasar Pendampingan Dan Konseling Pastoral. Jakarta: BPK Gunung Mulia, 2002.

Dachi, Otoriteit, Delipiter Lase, Yunelis Ndraha, Gustav Gabriel Harefa, Fotani Ziliwu, and Amurisi Ndraha. Pergumulan Di Sekitar Gereja Dan Pendidikan. Edited by Delipiter Lase and Fotani Ziliwu. Yogyakarta: Andi Offset, 2019.

Hornby, A.S., and A.P. Cowie. Oxford Advanced Learner's Dictionary of Current English. 5th ed. Oxford University Press, 1995.

Kusnan, Ahmad. "Analisis Sikap Iklim Organisasi, Etos Kerja Dan Disiplin Kerja Dalam Menentukan Efektifitas Kinerja Organisasi Di Garnizun Tetap III Surabaya." Universitas Airlangga, 2004. http://repository.unair.ac.id/id/eprint/3593 3.

Lase, Delipiter, and Etty Destinawati Hulu. “Dimensi Spritualitas Dalam Kompetensi Kepribadian Guru Pendidikan Agama Kristen." SUNDERMANN Jurnal Ilmiah Teologi Pendidikan Sains Humaniora dan Kebudayaan (2020).

Lincoln, Yvonna S, and Egon G Guba. Naturalist Inquiry. Beverly Hills, CA: Sage, 1985.

Merriam-Webster Incorporated. “Merriam-Webster Dictionary." Merriam-Webster. Encyclopædia Britannica, Inc., 2018. Last modified 2018. https://www.merriam-webster.com/.

Miles, M.B; Huberman, A.M; Sadana, J. “Chapter 4 Analyzing Qualitative Data." In Qualitative Data Analysis - A Methods Sourcebook, 2015.

Mondy, R. Wayne, Robert M. Noe, and Shane R. Premeaux. Human Resource Management. 9th ed. New Jersey: Prentice Hall, 2005.

Neuman, W. L. Metodologi Penelitian Sosial: Pendekatan Kualitatif Dan Kuantitatif. 7th ed. Jakarta: PT. Index, 2016.

Novliadi, Ferry. "Hubungan Antara OrganizationBased Self-Esteem Dengan Etos Kerja." Universitas Sumatera Utara, 2009. http://repository.usu.ac.id/bitstream/handl e/123456789/3626/08E00921.pdf?sequence= $1 \&$ isAllowed $=y$.

Pekerti, Anugerah, and Jansen H. Sinamo. Kompetensi Etis Dan Spiritual, Keniscayaan Pemimpin Abad Ke-21. Jakarta: Unit Publikasi dan Informasi STT Jakarta, 2001.

Rosmiani. “Etos Kerja Nelayan Muslim Di Desa Paluh Sebaji Deli Serdang Sumatera Utara: Hubungan Antara Kualitas Keagamaan Dengan Etos Kerja." Institut Agama Islam Negeri Jakarta, 1996.

Rothlisberger, H. Homiletika. 20th ed. Jakarta: BPK Gunung Mulia, 2006.

Salamun, Sumardi, Emiliana Sadilah, Sumintarsih, Suhartinah Sudijono, and Sukari. Persepsi Tentang Etos Kerja: Kaitannya Dengan Nilai Budaya Masyarakat Daerah Istimewa Yogyakarta. CV.EKA PUTRA, 1995. http://repositori.kemdikbud.go.id/12367/.

Sanders, J. Oswald. Spiritual Leadership: Principles of Exellence for Every Believer. Chicago: Moody Publishers, 2007.

Sinamo, Jansen. Delapan Etos Kerja Profesional: Navigator Anda Menuju Sukses. Bogor: Grafika Mardi Yuana, 2005.

Soewarsono, Rahardjo, Subagyo, and Utomo. Persepsi Tentang Etos Kerja Kaitannya Dengan Nilai Budaya Masyarakat. Jakarta: CV. Bupara Nugraha, 1995.

Suleeman, Ferdinand, Adji Ageng Sutama, and A. Rajendra, eds. Struggling in Hope: A Tribute to the Rev. Dr. Eka Darmaputera. 1st ed. Jakarta: BPK Gunung Mulia, 1999.

Taylor, S. J., Bogdan, R., \& DeVault, M. Introduction to Qualitative Research Methods: A Guidebook and Resource (4th Edition). New York: John Wiley $\mathcal{E}$ Sons, 2015. 
Telaumbanua, Tuhoni. "Kaum Milenial \&amp; Kebudayaan Nias." SUNDERMANN Jurnal Ilmiah Teologi Pendidikan Sains Humaniora dan Kebudayaan 1, no. 1 (October 2019): 1-16.

Trull, Joe E., James E. Carter, Samuel Septino Saragih, and N. Susilo Rahardjo. Etika Pelayan Gereja: Peran Moral Dan Tanggung Jawab Etis Pelayan Gereja. Jakarta: BPK Gunung Mulia, 2015.

Weber, Max. The Protestant Ethic and the Spirit of Capitalism. The Protestant Ethic and the Spirit of Capitalism. Routledge, 2005. https://www.taylorfrancis.com/books/9780 203995808.

- - . The Protestant Ethic and The Spirit of Capitalism. New York: Scribner, 1958.

Yeo, Anthony. Konseling: Suatu Pendekatan Pemecahan Masalah. Jakarta: BPK Gunung Mulia, 1999.

Zaluchu, Sonny Eli. "Strategi Penelitian Kualitatif Dan Kuantitatif Di Dalam Penelitian Agama." Evangelikal: Jurnal Teologi Injili dan Pembinaan Warga Jemaat 4, no. 1 (2020): 28-38.

American Heritage Dictionary of the English Language. 5th ed. Houghton Mifflin Harcourt, 2018. 